\title{
Argulus elongatus (Branchiura, Argulidae) in fish in the upper São Francisco river, Brazil
}

\author{
Argulus elongatus (Branchiura, Argulidae) de peixes do alto rio São Francisco, Brasil \\ Rayane Duarte $^{1 *}$ (1); Maria de Fátima Cancella de Almeida-Berto1; Caroline Ferreira Calvario²; \\ Michelle Daniele dos Santos-Clapp³; Marilia de Carvalho Brasil-Sato ${ }^{3}$ \\ ${ }^{1}$ Programa de Pós-graduação em Ciências Veterinárias, Instituto de Veterinária, Universidade Federal Rural do Rio de Janeiro - UFRRJ, \\ Seropédica, RJ, Brasil \\ ${ }^{2}$ Instituto de Ciências Biológicas e da Saúde - ICBS, Universidade Federal Rural do Rio de Janeiro - UFRRJ, Seropédica, RJ, Brasil \\ ${ }^{3}$ Laboratório de Biologia e Ecologia de Parasitos, Departamento de Biologia Animal, Instituto de Ciências Biológicas e da Saúde - ICBS, \\ Universidade Federal Rural do Rio de Janeiro - UFRRJ, Seropédica, RJ, Brasil
}

\begin{abstract}
How to cite: Duarte R, Almeida-Berto MFC, Calvario CF, Santos-Clapp MD, Brasil-Sato MC. Argulus elongatus (Branchiura, Argulidae) in fish in the upper São Francisco river, Brazil. Braz J Vet Parasito/ 2020; 29(2): e016119. https://doi.org/10.1590/ S1984-29612020010
\end{abstract}

\begin{abstract}
Among 164 fish from the upper São Francisco river, caught in the Três Marias reservoir (18 12' 59" S; 45 17' 34" W)

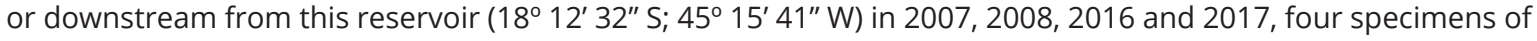
Argulus elongatus Heller, 1857 were found, one specimen per fish, in the following host species: Brycon orthotaenia Günther (two fish parasitized out of 38 examined) and Salminus hilarii Valenciennes (one fish parasitized out of 45 examined) (both in Bryconidae); and Metynnis lippincottianus (Cope) (one fish parasitized out of 81 examined) (Serrasalmidae). This opportunistic ectoparasite deserves attention even in the case of low infestation in fish in a natural water system. This is the first record of a branchiuran species in B. orthotaenia; the host list of $A$. elongatus is extended through addition of the three fish species examined in this study, and the known Brazilian geographical distribution of this argulid is enlarged to the São Francisco river basin.
\end{abstract}

Keywords: Fish ectoparasite, fish lice, Brycon orthotaenia, Salminus hilarii, Metynnis lippincottianus.

\section{Resumo}

De 164 peixes do alto rio São Francisco, capturados no Reservatório de Três Marias (18 12' 59" S; 45 17' 34" O) ou à jusante dele (18 12' 32" S; 45 15'41" O), em 2007, 2008, 2016 e 2017, quatro espécimes de Argulus elongatus Heller, 1857 foram encontrados, sendo um branquiúro por peixe nas seguintes espécies de hospedeiros: Brycon orthotaenia Günther (dois peixes parasitados de 38 peixes examinados), Salminus hilarii Valenciennes (um peixe parasitado de 45 examinados) - ambos Bryconidae, e Metynnis lippincottianus (Cope) (um peixe parasitado de 81 examinados) - Serrasalmidae. Esse ectoparasito oportunista merece atenção, mesmo no caso de infestações baixas em peixes de ambientes hídricos naturais. Esse é o primeiro registro de Branchiura em $B$. orthotaenia. A lista de hospedeiros de $A$. elongatus é ampliada com a adição das três espécies de peixes examinadas neste estudo. A distribuição geográfica conhecida desse argulídeo no Brasil, é ampliada para a bacia do rio São Francisco.

Palavras-chave: Ectoparasitos de peixes, piolhos de peixe, Brycon orthotaenia, Salminus hilarii, Metynnis lippincottianus.

The basin of the São Francisco river is the largest hydrographic basin in Brazilian territory. Its ichthyofauna is diverse, with socioenvironmental importance, especially for fishing (Godinho \& Godinho, 2003). Several groups of parasites have been recorded in fish from the Três Marias reservoir, on the upper São Francisco river, including Branchiura (Brasil-Sato, 2003). 
Branchiura is a group of crustaceans that usually parasitizes both freshwater and saltwater fish and is recognized by fishermen and fish farmers as 'fish lice' (Lemos de Castro, 1985; Thatcher, 2006). They parasitize the surface of the body, fins, buccal cavity and gills of fish and can occasionally parasitize amphibians, reptiles and some invertebrates (Ringuelet, 1943; Poly, 2008). Argulidae is the only family in Branchiura and it comprises four genera: Argulus Müller, 1785, Chonopeltis Thiele, 1900, Dipteropeltis Calman, 1912, and Dolops Audouin, 1837. This family has the highest diversity of genera and species occurring in the Afrotropical and Neotropical regions, in comparison with other biogeographical areas of the world: Nearctic, Oriental, Palearctic, Australasia with Pacific Ocean islands and Antarctica (Poly, 2008).

Reports of injuries to fish caused by argulids have included blood and tissue consumption at the puncture site; fungal infections at the puncture site; and transmission of viral and bacterial diseases (Thatcher, 2006; Poly, 2008; Woo \& Buchmann, 2012). These reports highlight the importance of reporting occurrences of these ectoparasites, even when they are uncommon in the fish communities of natural water systems.

In 2007, 2008, 2016 and 2017, a total of 164 fish specimens were caught by artisanal fishermen in the upper São Francisco river, state of Minas Gerais, Brazil. Among these, 139 fish were caught in the Três Marias reservoir $\left(18^{\circ} 12^{\prime} 59^{\prime \prime} \mathrm{S} ; 45^{\circ} 17^{\prime} 34^{\prime \prime} \mathrm{W}\right)$, consisting of 13 specimens of B. orthotaenia Günther, 1864 (in 2008) and 45 of S. hilarii Valenciennes, 1850 (33 fish in 2007, and 12 in 2016) (both in Bryconidae); and 81 of M. lippincottianus (Cope, 1870) (67 in 2016, and 14 in 2017) (Serrasalmidae). The other 25 fish (B. orthotaenia, in 2016) were caught in the São Francisco river ( $18^{\circ} 12^{\prime} 32^{\prime \prime} \mathrm{S} ; 4^{\circ} 15^{\prime} 41^{\prime \prime} \mathrm{W}$ ), downstream from the Três Marias dam.

The fish caught in 2007 and 2008 were individually fixed in bottles filled with 3\% formalin and those caught in 2016 and 2017 were individually packaged in plastic bags and frozen. These fish were transported from the Três Marias Integrated Center for Fishery and Aquiculture Resources (Centro Integrado de Recursos Pesqueiros e Aquicultura de Três Marias; $1^{\text {st }} \mathrm{CIT}$ ), state of Minas Gerais, Brazil, which belongs to the Development Company of the São Francisco and Parnaíba Valleys (Companhia de Desenvolvimento dos Vales do São Francisco e Parnaíba; CODEVASF), to the Parasite Biology and Ecology Laboratory of the Federal Rural University of Rio de Janeiro (Universidade Federal Rural do Rio de Janeiro), Seropédica, state of Rio de Janeiro, southeastern Brazil, for parasitological analysis. The mean total body length and respective minimum and maximum values of each fish were recorded: $B$. orthotaenia: 34.1 (23.0-50.0 cm); S. hilarii: $26.7(19.5-41.0 \mathrm{~cm})$; and M. lippincottianus: $14.0(9.0-19.0 \mathrm{~cm})$.

The fish classification followed Reis et al. (2003) and Froese \& Pauly (2019); the voucher specimens were deposited in the Zoology Museum of the University of São Paulo (MZUSP): B. orthotaenia (95166) and M. lippincottianus (95160). The classification of family and genus levels of the branchiurans followed Lemos de Castro (1985) and Thatcher (2006); and the argulid species were identified in accordance with Thiele (1904). The ectoparasite specimens were mounted on temporary slides using Amann's lactophenol for morphological evaluation and to make photomicrographs using an Olympus BX41 light microscope. Voucher specimens of the parasitic argulids were deposited in liquid medium ( $70^{\circ} \mathrm{GL}$ ethanol) in the Crustacea Collection of the National Institute for Amazon Research (Instituto Nacional de Pesquisas da Amazônia; INPA): 2501 (B. orthotaenia), 2503 (S. hilarii) and 2502 (M. lippincottianus). The ecological parameters of prevalence (P), mean intensity (MI) and mean abundance (MA) were determined as described by Bush et al. (1997).

A total of four specimens of crustaceans were identified as Argulus elongatus Heller, 1857 (Figure 1), which is located in Maxillopoda, Branchiura, Arguloida, Argulidae, were found on the body surface of four fish: two ectoparasites (one in each) in two specimens of $B$. orthotaenia from the São Francisco river in October 2016, out of 38 examined $(P=5.3 \%, M I=1.0, M A=0.05)$; one ectoparasite in one of S. hilarii from the Três Marias reservoir in October 2016, out of 45 examined $(P=2.2 \%, M I=1.0, M A=0.02)$; and one ectoparasite in one of $M$. lippincottianus from the Três Marias reservoir in July 2017, out of 81 examined $(P=1.2 \%, M I=1.0, M A=0.01)$.

Argulus elongatus is considered to be a generalist parasite, and was recorded with low prevalence in the three host species in the current study. Nonspecificity is inherent among argulid species. Hence, specimens of a particular species can be found in several species of fishes and, conversely, a single fish can be parasitized by different species of argulids. In addition, these branchiurans can easily move from one point to another on the host, and they are able to swim swiftly through the thoracic appendages. These characteristics help in understanding the diversity of fish species that they can parasitize (Lemos de Castro, 1985).

This opportunistic ectoparasite deserves attention because it can cause several types of injury to its hosts through spoliation and trauma in the tissues. The severity of injuries depends on the intensity of infestation, such that numerous lesions are often sites that allow secondary infections. These parasites can have a serious impact 


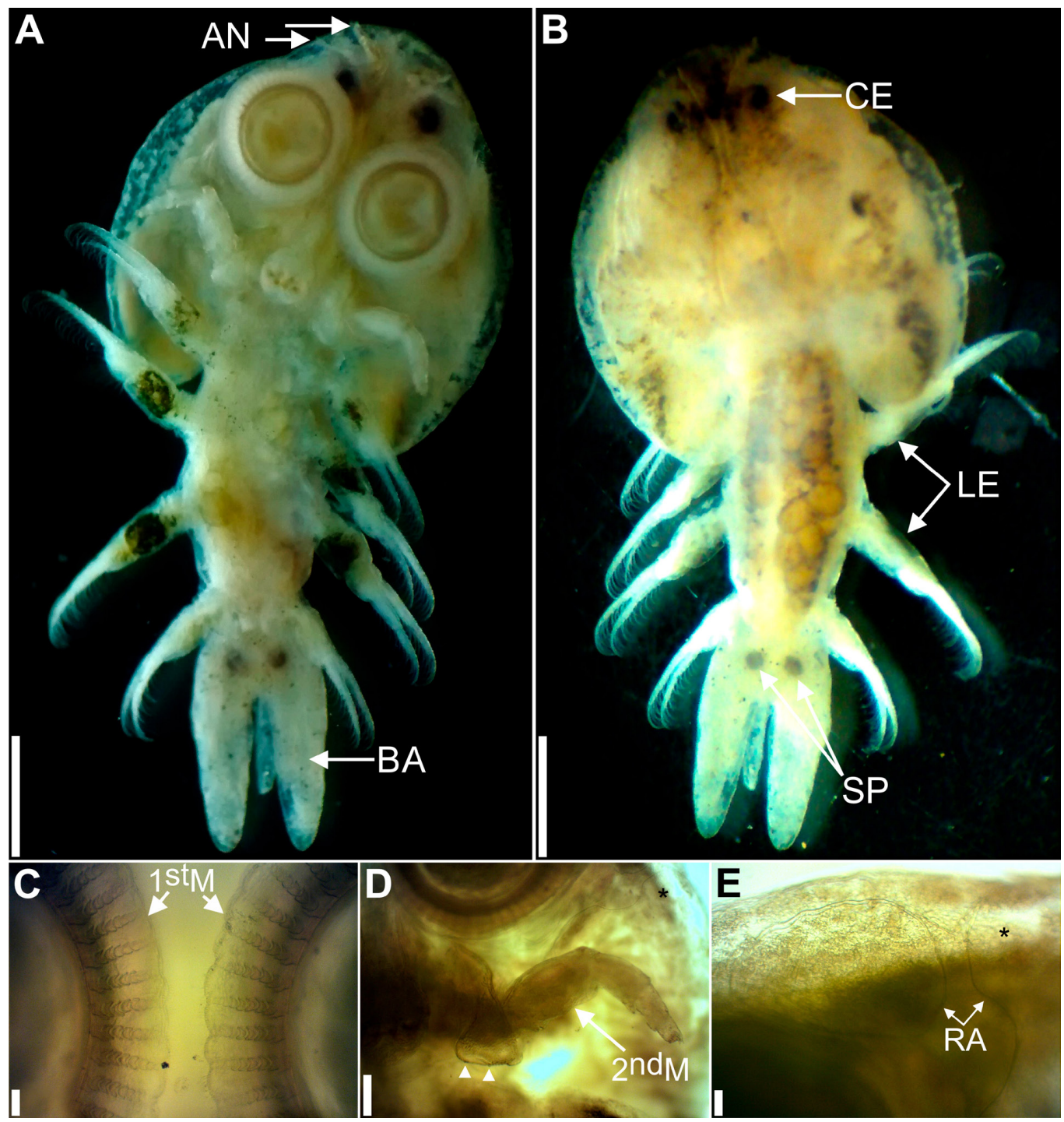

Figure 1. A-E: Argulus elongatus Heller, 1857, found on Salminus hilarii Valenciennes, 1850, from the Três Marias reservoir, on the upper São Francisco river, state of Minas Gerais, Brazil. Female adult specimen clarified with Amann's lactophenol: Photo A (ventral overview) - AN: antennae, BA: bilobed abdomen, scale = $1 \mathrm{~mm}$; Photo B (dorsal overview) - CE: compound eyes, LE: legs, SP: spermathecae, scale $=1 \mathrm{~mm}$; Photo $\mathrm{C}$ (first maxilla) $-1^{\text {st }} \mathrm{M}$ : first maxilla, detail of the chitinous support rods of suction cups, scale $=50 \mu \mathrm{m}$; Photo D (second maxilla) - $2^{\text {nd }}$ M: second maxilla, arrows indicate maxillary teeth, *indicates partial respiratory area (as shown in Photo E), scale $=200 \mu \mathrm{m}$; Photo E (region near the first maxilla) - RA: partial respiratory area, *indicates same region as in Photo $D$, scale $=50 \mu \mathrm{m}$.

on farmed fish, mainly because these fish are concentrated in small areas or held under semi-confinement, but may also affect fish from natural water systems (Kabata, 1970; Thatcher, 2006; Poly, 2008).

In the São Francisco river, Brasil-Sato (2003) cited a finding of the argulid Argulus multicolor Stekhoven, 1937, in Salminus brasiliensis (Cuvier, 1816) [= S. franciscanus Lima \& Britski, 2007], with the indexes $\mathrm{P}=2.8 \%, \mathrm{Ml}=7.0$ and MA = 0.2, which was reported in: Tavares, R.O. \& Brasil-Sato, M.C. Parasitos de brânquias de Salminus brasiliensis (Cuvier, 1817) (Osteichthyes, Characidae) do Rio São Francisco, MG, Brasil. Annals of "XI Jornada de Iniciação Científica da UFRRJ", v. 11, n. 1, p. 355-356, 2001. Edur: Seropédica, RJ, ISSN 1518-5680. Brasil-Sato (2003) also reported an occurrence of Dolops sp. in Hoplias lacerdae Miranda-Ribeiro, 1908 [= H. intermedius (Günther, 1864)], from a record made in 1994 by Narcisa Imaculada Brant Moreira in her master's dissertation in the Institute of Biological Sciences of the Federal University of Minas Gerais (Universidade Federal de Minas Gerais), state of Minas Gerais, Brazil.

Among the hosts analyzed in the present study, S. hilarii and M. lippincottianus are known to have geographical distribution outside of the São Francisco river (Shibatta \& Garavello, 1993; Sato \& Sampaio, 2006). Salminus hilarii was recorded as a host in Brazil for Argulus paulensis Wilson, 1924, according to Thatcher (2006); while M. lippincottianus 
in the Igarapé Fortaleza basin, a tributary of the Amazon river, in Macapá, state of Amapá, was recorded as a host for the argulid Dolops longicauda Heller, 1857 (Hoshino \& Tavares-Dias, 2014).

Argulus elongatus was described by Heller in 1857 from a female specimen that was very poorly preserved in the zoological collection of the Natural History Museum of Vienna (Naturhistorischen Museum Wiener), in Austria (Thiele, 1904), which originated from an unidentified host in Brazil (Thiele, 1904; Moreira, 1913). This type specimen was reexamined and illustrated (Thiele, 1904). In Brazil, A. elongatus among other branchiurans species, was recorded in Pygocentrus nattereri Kner, 1858, Serrasalmus marginatus Valenciennes, 1837, and Serrasalmus spilopleura Kner, 1858. These are all serrasalmid fish living in the Miranda river basin of the Pantanal wetland, state of Mato Grosso do Sul (Carvalho et al., 2003). Recently, A. elongatus was recorded in Leporinus fasciatus (Bloch, 1794) [Anostomidae] and P. nattereri from the Matapi River, state of Amapá (Neves \& Tavares-Dias, 2019).

Now, through the present study, one endemic species, $B$. orthotaenia, and one nonendemic species, S. hilarii (both in Bryconidae), and one introduced fish species, M. lippincottianus (Serrasalmidae), are also added as known hosts for $A$. elongatus in the São Francisco river basin. It is noteworthy that, over the years, not as many records of $A$. elongatus have been published as have been for its congeners. Therefore, a more detailed description of this ectoparasite is required, considering its hosts and its geographical distribution. As contributions to this, the present study adds three species of fish to the host list of $A$. elongatus, and the São Francisco river basin is added to the known geographical distribution of this ectoparasite species in Brazil.

\section{Acknowledgements}

The authors are grateful to Dr Yoshimi Sato and Dr Edson Vieira Sampaio (1 ${ }^{\text {st }}$ CIT/CODEVASF) for material and logistical support; to Dr Célio Magalhães, the curator of the Crustacea Collection, INPA, for deposition of voucher specimens. This study was financed in part (Master's scholarships R Duarte and a Scientific Initiation scholarships CF Calvario) by the Coordenação de Aperfeiçoamento de Pessoal de Nível Superior - Brasil (CAPES) - Finance Code 001; and by the Conselho Nacional de Desenvolvimento Científico e Tecnológico (CNPq) for the granting of Master's scholarships (MFC Almeida-Berto), and for financial support (Basic Parasitology Edict 2012).

\section{References}

Brasil-Sato MC. Parasitos de peixes da bacia do São Francisco. In: Godinho HP, Godinho AL. Águas, peixes e pescadores do São Francisco das Minas Gerais. Belo Horizonte: PUC Minas; 2003. p. 149-165.

Bush AO, Lafferty KD, Lotz JM, Shostak AW. Parasitology meets ecology on its own terms: Margolis et al. revisited. J Parasitol 1997; 83(4): 575-583. http://dx.doi.org/10.2307/3284227. PMid:9267395.

Carvalho LN, Del-Claro K, Takemoto RM. Host-parasite interaction between branchiurans (Crustacea: Argulidae) and piranhas (Osteichthyes: Serrasalminae) in the Pantanal wetland of Brazil. Environ Biol Fishes 2003; 67(3): 289-296. http://dx.doi. org/10.1023/A:1025899925545.

Froese R, Pauly D, editors. 2019. Fishbase. World Wide Web eletronic publication. Version (02/2019) [online] [cited 2019 Jun 28]. Available from: http://www.fishbase.org/search.php

Godinho AL, Godinho HP. Breve visão do São Francisco. In: Godinho HP, Godinho AL. Águas, peixes e pescadores do São Francisco das Minas Gerais. Belo Horizonte: PUC Minas; 2003. p. 15-24.

Hoshino MDFG, Tavares-Dias M. Ecologia parasitária de Metynnis lippincottianus (Characiformes: Serrasalmidae) da região da Amazônia oriental, Macapá, Estado do Amapá, Brasil. Acta Sci Biol Sci 2014; 36(2): 249-255. http://dx.doi.org/10.4025/actascibiolsci. v36i2.19876.

Kabata Z. Diseases of fishes: crustacea as enemies of fishes. Jersey City, USA: TFH; 1970.

Lemos de Castro A. Branchiura. In: Schaden R. Manual de identificação de invertebrados límnicos do Brasil. Brasília: CNPq/MCT; 1985. p. 1-23.

Moreira C. Historia natural: zoologia, crustaceos. Comissão de Linhas Telegraphicas Estratégicas de Matto-Grosso ao Amazonas. 1913. 21 p. Anexo 5.

Neves LR, Tavares-Dias M. from the Matapi River in the state of Amapá, Brazil. Rev Bras Parasitol Vet 2019; 28(3): 493-498. http:// dx.doi.org/10.1590/s1984-29612019006. PMid:31188939.

Poly WJ. Global diversity of fishlice (Crustacea: Branchiura: Argulidae) in freshwater. Hydrobiologia 2008; 595(1): 209-212. http:// dx.doi.org/10.1007/s10750-007-9015-3. 
Argulus elongatus (Branchiura, Argulidae)

Reis RE, Kullander SO, Ferraris CJ. Check list of the freshwater fishes of South and Central America. Porto Alegre: EDIPUCRS; 2003. Ringuelet R. Revisión de los Argúlidos Argentinos (Crustácea. Branchiura) con el catálago de las especies neotropicales. Rev Museo de La Plata 1943; 3(19): 43-100.

Sato Y, Sampaio EV. A ictiofauna do Reservatório de Três Marias, Rio São Francisco, Minas Gerais. Belo Horizonte: FUNDEP-UFMG/ SECTESMG; 2006.

Shibatta OA, Garavello JC. Estudo da variação geográfica em Salminus hilarii Valenciennes, 1849, das bacias do Alto Paraná e São Francisco, através da análise morfométrica multivariada em componentes principais. Naturalia (Sao Jose Rio Preto) 1993; 18: 109-116.

Thatcher VE. Amazon fish parasites. 2nd ed. Sofia, Moscow: Pensoft Publishers, 2006.

Thiele J. Beiträge zur Morphologie der Arguliden. In: Zoologisches Museum in Berlin. Mitteilungen aus dem Zoologischen Museum, Berlin (4th ed.). Berlin: R. Friedländer \& Sohn, 1904. v. 2, p. 1-51. Mit 4 Tafeln (6-9).

Woo PT, Buchmann K. Fish parasites: pathobiology and protection. London: CABl; 2012. http://dx.doi.org/10.1079/9781845938062.0000 